right fork of a branch from a tree. The other two are hanging nests. One is loosely constructed of straws and lined inside with fine grass, but too small to be an oriole nest, the other is a sturdy round nest built of fine grass and covered with a stiff, sticky white cotton-like substance which gives this nest its trim strength. Maybe these are vireos' nests, but what kind?

\title{
A Gyrfalcon Observation
}

by Jacob H. Jmaeff, Kamsack, Saskatchewan

On March 29, 1959, I observed what I believed to be a Gyrfalcon in its white phase.

We were driving by car in an area five miles south, one and a half miles east of the town of Kamsack. We saw a white bird sitting on a fence post.

As the car approached the bird took flight and flew northward. As it took flight we noticed its complete white coloration and pointed wings.

When we arrived home I consulted the Peterson Field Guide series and concluded that the bird was a Gyrfalcon in its white phase.

\section{"Rabbits' Picnic"}

by Marjorie Wardlaw, age 6 , Rhein, Sask.

One night when we were coming to the school with the truck we saw about thirty big jack rabbits playing on the snowbanks. The truck lights scared them and they all ran away, some one way and some another way.

\section{A Strange World}

by Wayne Bernakevitch, age 11, Kelliher, Sask.

This happened in the year 1958, July 23. Some of my friends and I were out walking in the bushes, when all of a sudden we heard a noise. We looked up and in a tree we saw a duck's nest and about ten feet away a magpie's nest. One of my friends climbed up and looked at the magpie's nest; there were babies in it and from that location we could see a mother duck sitting on her eggs. When she saw us she flew away. Then I told my friend in the tree the mother of the baby magpies was coming, so he got down and we all went away, but we all wondered why the magpie didn't harm the duck.

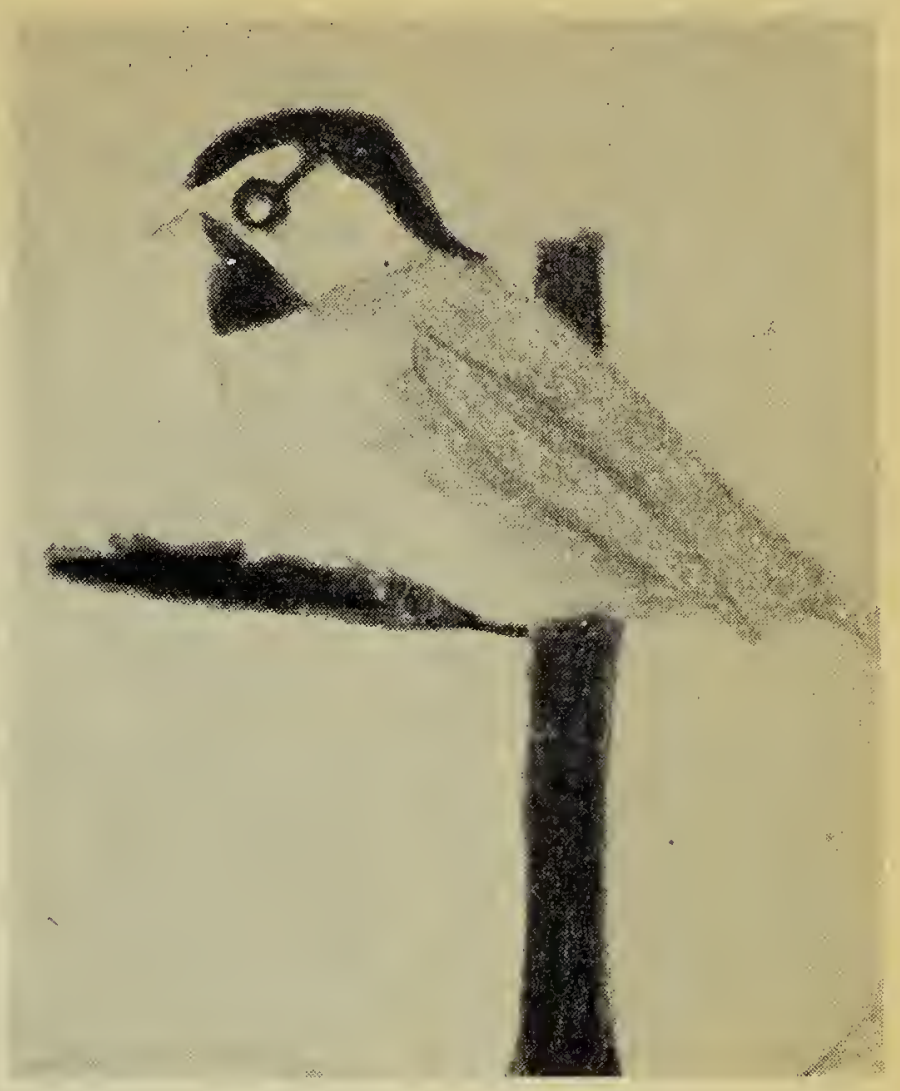

CHICKADEE

Gail Dereniwsky, Age 8,

Grade 3, Kitzman School.

\section{Howling Coyote}

by Eunice Gawdun, age 7, Calder, Sask.

One morning in March I saw a coyote in an open field. He sat down, lifted his head up and began to howl. His colour is gray. He looked just like a dog.

\section{The Porcupine}

by Mildred Bcon, age 11,. Maryfield, Sask.

One day while we were looking out of a school window, we saw a black spot which looked much like a stone. Then it moved!

After school three of us went out to investigate. Approaching it we saw it was a porcupine. We slowed, wondering. if it was really true that a porcupine could throw quills. He ambled over to a clump of willow, then rolled up into a ball. One of us "went back to school for a camera. We wanted to see his face, so we threw a snowball at him. All it did was slap its tail. But once he looked up, then we snapped a picture. Finally we got up courage enough to go as close as a yard to him. When he didn't throw any quills at us we decided he couldn't. But I still wonder if you tamed a porcupine could you pet him? However, none of us were quite that brave. 